\title{
Democratic values and the judicial process
}

\author{
by Sir Roger Toulson
}

\begin{abstract}
The Sixth Annual Lecture to be presented to the Society for Advanced Legal Studies was given by Sir Roger Toulson, chairman of the Law Commission, on 11 June.
\end{abstract}

$\mathrm{T}$ consider the relationship between the judicial process and democratic values is to enter broad and deep waters. A combination of representative government and an independent judiciary requires constitutional adjustment of some kind or another. Economically, demographically and culturally our society is in a state of continuous change and development, and that process is likely to result in a rather slower process of change in the relationship between different organs of the state. It is likely to be slower because the institutions of a stable democracy are intended to provide a framework within which economic, social and cultural change can be accommodated without threat to the fabric of society. But it is part of the history of democracies that constitutional arrangements, whether written or conventional, do not remain static.

There are bound at times to be tensions. Presently there are two particular areas where serious concerns have been expressed either about the democratic appropriateness of the judicial process or about a gap of understanding between judiciary and the public. These concerns relate to judicial review and the Human Rights Act, and to criminal law and sentencing. On these subjects, the opinions held are likely to depend very much on the perspective from which they are viewed. I would like to try to take a broad approach, that of a landscapist rather that a miniaturist.

The Human Rights Act is in its early days. Its main provisions came into effect in October 2000. Professor Tom Campbell in his stimulating contribution (entitled Incorporation Through Interpretation) to a series of essays published under the title Sceptical Essays on Human Rights (OUP 2001) wrote that:

"What actually transpires will depend crucially on the use that the judiciary makes of the central provisions of the HRA, but the constitutional scene is now set for the legally legitimate but still democratically problematic exercise of greatly enhanced political power by judges in the British political system. Whereas it used to be commonplace to say that the absolute legal sovereignty of Parliament is in effect limited only by political considerations, the new interpretative powers granted to the courts by the HRA are powers that are

\begin{abstract}
now subject only to political factors, such as hostile public
\end{abstract} reaction to court decisions."

He further predicted that:

"It is realistic to assume that the prime long term impact of the ECHR will derive less from its content than from its displacement of the centrality of plain, literal or ordinary meaning [in the construction of statutes] in favour of a textually unrestrained process of enforcing particular judicial views of the proper goals of a democratic society."

Similar concerns have been voiced by others.

As everyone knows, many of the articles of the ECHR are expressed in very broad terms, and many are subject to exceptions where "necessary in a democratic society" for the protection of other values also expressed often in broad language. What is necessary in a democratic society therefore becomes a matter of legal judgement. Since the European Court of Human Rights has stressed that the Convention is a living instrument, it is open to the judges to develop and refine what is necessary in a democratic society according to the views of the judiciary and to interpret legislation in accordance with that view, even if that is not its natural meaning, unless the language is so precise as to make such interpretation impossible (in which case the court can make a declaration of incompatibility).

The ability of judges to give to a statute a non-natural meaning in order to comply with the judge's view of what is necessary in a democratic society, and to apply it accordingly, is in some ways a more pervasive power than the power to make a declaration of incompatibility while applying the statute according to its terms. How then is a judge to determine what is necessary in a democratic society?

There has always been a potential conflict between democracy and the rights of individuals, and this is a problem for all liberal forms of government. In modern liberal societies there have been two principal avenues of thought about what gives legitimacy to a system of government - the will of the people and the rights of the people. 
According to the first avenue, the adult members of a society have equal rights to determine what is best for their society. This provides the basis for government by representatives chosen by free elections at regular intervals. What these representatives decide has legitimacy because they represent the voice of the people.

In his Considerations on Representative Government in 1861 John Stuart Mill wrote:

"There is no difficulty in showing that the ideally best form of government is that in which the sovereignty, or supreme controlling power in the last resort, is vested in the entire aggregate of the community; every citizen not only having a voice in the exercise of that ultimate sovereignty, but being, at least occasionally, called on to take an actual part in the government, by the personal discharge of some public function, local or general."

The proposition that this was the ideal form of government rested, he said:

"Upon two principles, of as universal truth and applicability as any general propositions which can be laid down respecting human affairs. The first is, that the rights and interests of every or any person are only secure from being disregarded when the person interested is himself able, and habitually disposed, to stand up for them. The second is, that the general prosperity attains a greater height, and is more widely diffused, in proportion to the amount and variety of the personal energies enlisted in promoting it."

Mill emphasised that he was speaking of what was ideal. He recognised that a majority might act in ways which were unfair to minorities. He said:

"One of the greatest dangers of democracy as of all other forms of government lies in the sinister interest of the holders of power... And one of the most important questions demanding consideration, in determining the best constitution of a representative government, is how to provide efficacious securities against this evil."

He expressed the aim that "the representative system ought not to allow any of the various sectional interests to be so powerful as to be capable of prevailing against truth and justice". He was therefore not an out-and-out majoritarian.

But how should "truth and justice", against which majoritarian government should not be allowed to prevail, be ascertained and protected? Mill did not suggest a clear or precise answer, although he did propose that there should be parliamentary checks and balances through extended suffrage, proportional representation and a reformed second chamber, and he was adamant that politics and majoritarian opinion should play no part in the appointment or removal of judges. As to the last point he said:

"Of all officers of government, those in whose appointment any participation of popular suffrage is the most objectionable are judicial officers. ... There are none in whose case absolute impartiality, and freedom from connection with politicians or sections of politicians, are of anything like equal importance. Some thinkers, among others Mr Bentham, have been of opinion that, although it is better that judges should not be appointed by popular election, the people of their district ought to have the power, after sufficient experience, of removing them from their trust. It cannot be denied that the irremovability of any public officer, to whom great interests are entrusted, is in itself an evil. It is far from desirable that there should be no means of getting rid of a bad or incompetent judge, unless for such misconduct as he can be made to answer for in a criminal court; and that a functionary on whom so much depends should have the feeling of being free from responsibility except to opinion and his own conscience. The question however is, whether in the peculiar position of a judge, and supposing that all practicable securities have been taken for an honest appointment, irresponsibility, except to his own and the public conscience, has not on the whole less tendency to pervert his conduct than responsibility to the government or to popular vote. Experience has long decided this point in the affirmative as regards responsibility to the executive; and the case is quite equally strong when the responsibility sought to be enforced is to the suffrages of electors. Among the good qualities of a popular constituency, those peculiarly incumbent upon a judge, calmness and impartiality, are not numbered."

According to the second principal avenue of thought, human beings have individual rights. Orderly society necessitates the placing of limits on what its members are free to do, but the proper object of the system of government is to provide the best available protection of those rights on an equal basis for all its members.

Metaphorically, the majoritarian principle and the rights principle may be seen as two poles, around which liberal systems of government have developed. The tensions between the two polar forces have been accommodated through checks and balances. A further reason for having checks and balances is that all human institutions have their fallibilities. In the words of Professor Isaiah Berlin, adapted from Kant, "Out of the crooked timber of humanity nothing entirely straight was ever made" - a saying which applies to the judicial process as much as to any other.

The Human Rights Act came at the end of a century which saw not only a vast increase in the powers of central government through primary and secondary legislation, much of it the subject of little parliamentary scrutiny, but also major changes in the checks and balances affecting the exercise of those powers.

A hundred years ago considerably less than half the adult population in the United Kingdom had the vote. The monarchy still had some real political power and the House of Lords had major political powers.

Today the monarch acts in constitutional matters on the advice of her ministers (save theoretically in circumstances 
so exceptional that they have not occurred during the present reign) and the House of Lords has dwindled to a high class debating chamber selected in an odd fashion. There is generally little check between the legislature and the executive because the government of the day (as long as it has a comfortable working majority) controls both.

But other checks have been developed. At the head of the list have been the introduction of universal adult suffrage and the expansion of the reach and role of the media. To digress briefly, the constitutional role of the media and the constitutional protections required for it are themselves interesting and important topics. The media have a number of functions: to inform the public; to raise questions about matters of public importance; to act as lobbyists; to entertain; and (except for public service broadcasters) to make profits for shareholders. In considering the constitutional protection which the media ought to have, I am not sure that we always consider with sufficient clarity this divergence of functions. The role of the media as part of the entertainment industry is very different from its role as a constitutional watchdog.

But I am presently concerned with judicial review and the Human Rights Act, which are undoubtedly important constitutional developments. I return to Professor Campbell's concerns. What is there to restrain the courts from exercising their powers in a way which is democratically illegitimate?

It has been recognised by the House of Lords that the courts should accord such deference, or respect, to the decisions of the legislature and the executive as may be appropriate, applying principles which are in the process of being fashioned. This important subject has been discussed in three recent high profile cases: International Transport Roth GmbH v Home Secretary [2003] QB 728, A v Home Secretary [2003] 2 WLR 564 and $R$ (Pro Life) v BBC [2003] 2 WLR 1403. In each of those cases the discussion was sharpened by a division of opinion among the judges.

The use of the term "deference" has become common, but it has a tendency to mislead for reasons stated by Lord Hoffman and echoed by Lord Walker in $R$ (Pro Life) $v$ BBC. Deference carries a flavour of a subordinate kow-towing to a superior, whereas the role of the court is intended to be complementary to those of the legislature and the executive.

The court has to decide on principles of law how far it should properly go in the review of legislative or executive decisions without usurping the proper functions of the legislature and the executive. Lord Walker said in $R$ (Pro Life) $\vee B B C$ that at this stage in the bedding down of the 1998 Act it would be a mistake for the courts to go too far in attempting any comprehensive statement of principle, but that it is clear that any simple "one size fits all" formulation would be impossible. In the USA, which has a Bill of Rights dating back to 1791 (although it is right to say that a serious system of judicial review based on non- property human rights did not begin until the early part of the twentieth century) there is still no single, comprehensive principle for determining the scope of judicial review, and I doubt very much whether we shall have one a hundred years from now. But while there may be no single formula waiting to be discovered, there are certainly lessons to be learned from the experiences of other jurisdictions, and our courts are in the process of recognising certain criteria or guidelines, the force of which may vary according to the particular facts of the case.

Laws LJ identified the following four general principles in his judgment in International Transport Roth GmbH $v$ Home Secretary: first, that greater deference is to be paid to an Act of Parliament than to a decision of the executive or subordinate measures; second, that there is more scope for deference where the Convention itself requires a balance to be struck; third, that greater deference will be due to democratic powers where the subject matter is peculiarly within their constitutional responsibility (e.g. defence of the realm) and less when it lies more particularly within the constitutional responsibility of the courts; and fourth, that greater or lesser deference will be due according to whether the subject matter lies more readily within the actual or potential expertise of the democratic powers or the courts.

Lord Goldsmith QC in a recent article in The Commonwealth Lawyer, Vol. 12, no. 1, page 38, entitled "Governing within the rule of law: the courts and the executive", took issue with the suggestion that as a matter of general approach greater deference should be paid to an Act of Parliament than to a decision of the executive or a subordinate measure, because it was over formalistic and failed to take adequate account of the way in which responsibility for decisions is allocated within our constitutional arrangements. He quoted Lord Steyn's saying in $R$ (Daly) v Home Secretary [2001] 2 AC 532 that "in law context is everything" and suggested four themes which should inform the court's consideration in any particular case. The first was whether the particular subject matter lies more within the field of expertise of the government (such as matters of macro economic policy or national security) or of the courts. The second was whether the subject matter by its nature requires "democratic legitimacy" and so should be left to those democratically accountable, for example because it involves contentious moral issues on which society is divided or is "highly political". The third was the nature of the Convention right engaged and, in particular, whether it is qualified or unqualified. The fourth was what he termed "the polycentricity factor", i.e. whether the quashing of a decision would have undesirable and unintended knock on effects in other areas.

It is clear that there is a healthy debate under way. The ideas to which I have referred are all thought provoking and there is a good degree of overlap between them. At the 
risk of over simplicity, it seems to me that in general three sets of factors are likely to be important in considering the limits the courts should set themselves: the nature of the right and context in which it is engaged; the obviousness or doubtfulness of the apparent or suggested infringement; and the degree of relevant knowledge or expertise of the legislature or executive compared with that of the court. Those factors may point in the same or different directions, and analysing them may call for careful judgment.

As to the nature of the right and its engagement, a large amount of legislation and executive decision making relates to matters of economic and social policy, where majoritarian power is bound to be the principal determinant of change under any form of elected government.

A hundred years ago Justice Oliver Wendell Holmes, in his first opinion in the Supreme Court, set out what still stands today as a lucid and cogent statement of the courts' proper approach to judicial review in such an area and the reasons for it. The case, Otis v Parker 187 US 606 (1903), concerned the constitutionality of a provision of the California constitution which made void any contract for the sale of company shares on margin or for delivery on a future day and provided that any money paid under such contract should be recoverable by the payer. Its constitutionality was challenged under the Fourteenth Amendment, which provides that no state shall deprive any person of liberty or property without due process of law; nor deny to any person within its jurisdiction the equal protection of the laws. It is loosely comparable in subject matter with Article 1 of the First Protocol to the ECHR, which is concerned with the protection of property, and Article 14, which is concerned with discrimination in the enjoyment of Convention rights. The objection to the provision was that it unlawfully interfered with the property rights of the owners of company stock, because it bore no reasonable relation to the evil sought to be cured; and that it unjustifiably discriminated against owners of that class of property compared with other forms of property in respect of which similar types of speculative contract were permitted.

Holmes wrote as follows:

"It is true, no doubt, that neither a state legislature nor a state constitution can interfere arbitrarily with private business or transactions, and that the mere fact that an enactment purports to be for the protection of public safety, health or morals, is not conclusive upon the courts. But general propositions do not carry us far. While the courts must exercise a judgment of their own, it by no means is true that every law is void which may seem to the judges who pass upon it excessive, unsuited to its ostensible end, or based upon conceptions of morality with which they disagree. Considerable latitude must be allowed for differences of view as well as for possible peculiar conditions which this court can know but imperfectly, if at all. Otherwise a constitution, instead of embodying only relatively fundamental rules of right, as generally understood by all English-speaking communities, would become the partisan of a particular set of ethical or economical opinions, which by no means are held semper ubique et ab omnibus.

Even if the provision before us should seem to us not to have been justified by the circumstances locally existing in California at the time when it was passed, it is shown by its adoption to have expressed a deep-seated conviction on the part of the people concerned as to what that policy required. Such a deep-seated conviction is entitled to great respect. If the state thinks that an admitted evil cannot be prevented expect by prohibiting a calling or transaction not in itself necessarily objectionable, the courts cannot interfere, unless, in looking at the substance of the matter, they can see that it "is a clear, unmistakable infringement of rights secured by the fundamental law." No court would declare a usury law unconstitutional, even if every member of it believed that Jeremy Bentham had said that the last word on that subject, and had shown for all time that such laws did more harm than good."

Holmes did not suggest that a state's power to frame its social and economic policy must in all circumstances override all other considerations. If, for example, a statute were to expropriate property without compensation, that would be in his words "a clear, unmistakable infringement of rights secured by the fundamental law"; but regulation of contracts and expropriation of property are different kettles of fish.

Although Holmes wrote for the majority in Otis $v$ Parker, he battled with his brethren on the court in the years that followed. In Lochner $v$ New York 198 USA 45 (1905) a majority of the Supreme Court struck down a New York statute which limited the number of hours of work in bakeries to ten hours a day and 60 hours a week on the ground that it infringed the employees' constitutional liberty to contract to work for longer hours. In a famous dissenting judgment, which in later years came to be accepted as a sound embodiment of principle, Holmes wrote:

"This case is decided upon an economic theory which a large part of the country does not entertain. If it were a question whether I agreed with that theory, I should desire to study it further and long before making up my mind. But I do not conceive that to be my duty, because I strongly believe that my agreement or disagreement has nothing to do with the right of a majority to embody their opinions in law. It is settled by various decisions of this court that state constitutions and state laws may regulate life in many ways which we as legislators might think as injudicious or if you like as tyrannical as this, and which equally with this interfere with the liberty to contract. Sunday laws and usury laws are aged examples. A more modern one is the prohibition of lotteries. The liberty of the citizen to do as he likes so long as he does 
not interfere with the liberty of others to do the same, which has long been a shibboleth for some well-known writers, is interfered with by school laws, by the Post Office, by every state or municipal institution which takes his money for purposes thought desirable, whether he likes it or not. The Fourteenth Amendment does not enact Mr Herbert Spencer's Social Statics ... Two years ago we upheld the prohibition of sales of stock on margins or for future delivery in the constitution of California. The decision sustaining an eight hour law for miners is still recent. Some of these laws embody convictions or prejudices which judges are likely to share. Some may not. But a constitution is not intended to embody a particular economic theory, whether of paternalism and the organic relation of the citizen to the state or of laissez faire. It is made for people of fundamentally differing views, and the accident of finding certain opinions natural and familiar or novel and even shocking ought not to conclude our judgment on the question whether the statutes embodying them conflict with the constitution of the United States.

... I think that the word liberty in the Fourteenth Amendment is perverted when it is held to prevent the natural outcome of a dominant opinion, unless it can be said that a rational and fair man necessarily would admit that the statute proposed would infringe fundamental principles as they have been understood by the traditions of our people and our law. It does not need research to show that no such sweeping condemnation can be passed upon the statute before us. A reasonable man might think it a proper measure on the score of health."

The battle within the Supreme Court in this area reached its climax when a majority ruled unconstitutional various statutes containing key parts of President Roosevelt's New Deal legislation. The President threatened to try to increase the size of the court and there was a constitutional crisis. It was resolved when one of the previous majority of five changed sides, provoking the quip that "a switch in time saves nine". (Justice Roberts changed his approach, beginning with Morehead v New York ex rel Tipaldo 298 US 587 (1936), where the court upheld a minimum wage law.)

While there are strong reasons why the courts should ordinarily keep out of the arena of economic and social policy in the exercise of their powers of judicial review, it has long been recognised that the courts are proper protectors of core personal freedoms, such as freedom from detention, freedom of movement and association, enjoyment of private and family life, freedom of speech and the right to a fair criminal trial process. There is in general no institutional reason why the courts should refrain from scrutinising strictly the legality of interference with those rights, and they have a responsibility to do so.

It follows that whether a court views a case as falling within the territory in which it should not normally intervene or as falling within a natural justiciable area may be of decisive importance.
International Transport Roth GmbH v Home Secretary provides a recent example. The case concerned the lawfulness of a penalty scheme imposed on lorry drivers and haulage companies under section 32 of the Immigration and Asylum Act 1999 making them liable to pay $£ 2000$ for every person caught trying to enter the country hidden in a vehicle. Sullivan J, in a judgment described by Simon Brown LJ as a tour de force, found that the scheme was unlawful. His decision was upheld by a majority of the Court of Appeal (Simon Brown and Jonathan Parker LJJ, Laws LJ dissenting). The majority classified the scheme as part of the criminal law. It has been held that, while various matters may have to be balanced in determining what amounts to a fair trial under Article 6, an accused person's right under that article to a fair trial is unqualified. The majority concluded that the scheme contravened Article 6 because it not only placed a reverse burden of proof on the carrier to show that he was blameless but also empowered the immigration authority to impound the carrier's vehicle until he had either put up security for a substantial fixed penalty or proved his innocence. They also considered that the scheme fell foul of Article 1 of the First Protocol (providing protection of property) but the judgments of the majority concentrated mainly on Article 6. The dissenting member of the court, Laws LJ, saw the scheme as a part of the civil law. Although it was draconian in relation to the carriers, he did not consider that a court could impugn the minister's evaluation that the scheme was necessary to combat the serious social evil at which it was aimed.

I have referred to core freedoms, but I would not advocate a rigid or formal hierarchy of rights, such as first generation rights and second generation rights (terms used by some), as a universal determinant of the appropriate degree of judicial self-restraint or strictness of scrutiny, because the form and context in which the issue arises may have an important bearing on the proper approach of the court. Nor does the fact that the issue involves consideration of a core freedom mean that the court must therefore assume the role of primary finder and evaluator of the facts. The court's concern is with legal principles and whether the legislation or decision under consideration is impeachable. That does not exclude a judgment area for the legislature or decision-maker the bounds of which must be respected by the court. Determining whether the matter under review is properly within those bounds may involve hard questions.

By way of illustration of these points, consider freedom of speech. Everyone recognises that it is a core freedom. It is protected by Article 10 of the Convention. In the USA it is protected by the First Amendment. In no country is it unqualified. In the USA the approach of the courts has been based on the philosophy that an unregulated market place of ideas is essential for the good of society as a whole.

In another of his dissenting opinions which later gained acceptance, Justice Holmes said: 
"... when men have realised that time has upset many fighting faiths, they may come to believe even more than they believe the very foundations of their own conduct that the ultimate good desired is better reached by free trade in ideas that the best test of truth is the power of the thought to get itself accepted in the competition of the market, and that truth is the only ground upon which their wishes can safely be carried out. That at any rate is the theory of our Constitution. It is an experiment, as all life is an experiment. Every year if not every day we have to wager our salvation upon some prophecy based upon imperfect knowledge. While that experiment is part of our system I think that we should be eternally vigilant against attempts to check the expression of opinions that we loathe and believe to be fraught with death, unless they so imminently threaten immediate interference with the lawful and pressing purposes of the law that an immediate check is required to save the country."

(Abrams v United States 250 US 616 (1919)).

This philosophy has not only come to be accepted, but it has been applied in ways which might seem surprising to some. An expert in US constitutional law, Professor Mark Tushnet, has observed that "the Supreme Court has developed free expression doctrine in a way that makes it almost impossible to enforce legislation restricting so called hate speech". ("Scepticism about judicial review: a perspective from the United States": published in Sceptical Essays on Human Rights, Oxford University Press 2001.)

This comment was based on a majority decision of the Supreme Court in RAV V City of St Paul 505 US 377 (1992), where the court struck down a hate speech ordinance on the ground that it was not "content neutral", because it prohibited fighting words of racists or sexists, but not those of individuals fighting racism or sexism. Justice Scalia, writing for the majority, said:

"St Paul has no authority to license one side to fight free style, while requiring the other to follow Marquess of Queensberry rules."

The Supreme Court has also decided that statutory restrictions on a political candidate's expenditures violate free expression.

An eminent critic, Professor Owen Fiss, has provided an interesting commentary on these and other recent US Supreme Court decisions in a book entitled "The Irony of Free Speech” (Harvard University Press, 1996). The irony to which he refers is that a doctrine of freedom of speech developed in order to promote and protect democratic self rule should be used, according to his argument, in a way which militates against democratic self rule by allowing the underdog to be intimidated or drowned out.

Professor Fiss observes that there is in truth a distinction to be drawn between a libertarian and a democratic theory of speech, and that the libertarian theory is unable to explain why the interests of speakers should take priority over the interests of those individuals who are discussed in the speech, or who must listen to the speech, when those two sets of interests conflict.

He also argues that:

"Content neutrality is not an end in itself and should not be reified. The principle responds to some underlying concern that the state might use its power to skew debate in order to advance particular outcomes, and this purpose should always be kept in mind. Accordingly, the principle should not be extended to situations like hate speech, pornography and political expenditures, in which private parties are skewing debate and the state regulation promotes free and open debate. In those cases the state may be disfavouring certain speakers - the cross-burner, the pornographer or the big spender - and make judgments based on content, but arguably only to make certain that all sides are heard. The state is simply acting as a fair-minded parliamentarian, devoted to having all views presented."

In this jurisdiction, $R$ (Pro Life) $v$ BBC raised an important question about the court's approach under Article 10, on which there was a sharp divergence of judicial opinion. During the last general election campaign Pro Life wanted to show pictures of aborted foetuses in a televised election broadcast. The BBC wrote on behalf of all the channels refusing to transmit the material on the grounds that by prevailing standards of taste and decency the images would be offensive to very large numbers of viewers. Independent broadcasters operate under licences granted by the Independent Television Commission, which is under a statutory duty (by section 6(1)(a) of the Broadcasting Act 1990) to do what it can to ensure that nothing is included in broadcast programmes which "offends against good taste or decency or is likely ... to be offensive to public feeling". The BBC operates under an agreement with the government which contains a similar requirement.

Pro Life argued that the broadcasters' refusal to screen the material infringed its rights under Article 10. Scott Baker J refused the application on the ground that Pro Life's right of free speech was qualified by reference to the rights of others, which included the rights of viewers not to be confronted with offensive material in their own homes, and that it was impossible to conclude that the decision to refuse to screen the material was irrational.

The Court of Appeal (at [2002] 3 WLR 1080) allowed an appeal by Pro Life, holding that the judge had adopted a mistaken approach. Laws LJ identified what he saw as the real issue in the case as being whether the considerations of taste and offensiveness which moved the broadcasters constituted a legal justification for the censorship involved in banning the proposed broadcast. Because of the importance of protecting political speech, particularly in the run up to a general election, the court had to decide for itself whether such censorship was justified. The reasonableness of the broadcasters' view was not the critical issue, and the weight to be attached to their opinion was modest. He accepted that there might be instances in 
which political speech might justifiably be censored on grounds of taste or offensiveness, but it would take a very extreme case. He held that freedom of political speech at a public election must not be interfered with save on the most pressing grounds, and that no such grounds had been established.

Simon Brown LJ identified the ultimate question for decision as being "whether the ban was necessary in a democratic society" under Article 10(2). He stressed that the importance of freedom of expression in the context of political speech was hard to exaggerate and, against that background, he concluded that there was no pressing social need to ban the broadcast.

The House of Lords, by a majority of four to one, disagreed with the approach of the Court of Appeal and restored the judgment of Scott Baker J. The majority held that the Court of Appeal had erred in failing to identify and distinguish between two different questions. The first was whether the standards of taste and decency imposed on broadcasters were lawfully applicable to party broadcasts as much as to other broadcasts. If so, the second question was whether the broadcasters had properly applied them. There was no explicit challenge by Pro Life to the lawfulness of the imposition of taste and decency standards on the broadcasters, and Lord Nicholls (with whom Lord Millett agreed) therefore did not consider it necessary to discuss the first question. Lord Hoffman took a different approach because he considered that, although Pro Life did not argue that the taste and decency requirements imposed on the broadcasters were inconsistent with its rights under Article 10, its argument entailed submitting that those requirements should be disregarded or not taken seriously. He therefore considered the taste and decency requirements and he concluded that the rationale for having such standards applied to political as well as to any other broadcasts; the standards were part of the country's cultural life and had created expectations on the part of viewers as to what they would and would not be shown on the screens in their homes. Lord Walker noted that the taste and decency requirements were in imprecise terms and called for a value judgment to be made. On the basis that the broadcasters were under an obligation to apply the taste and decency requirements, the majority agreed that the broadcasters could not be said to have done other than give effect to them.

A number of comments may be made. First, determining the point at which disturbing images become sufficiently offensive to wide numbers of the public that they ought not to be shown on television is obviously a difficult matter. It is one which broadcasters are better qualified to assess than judges, because broadcasters carry out surveys in order to gauge current levels of public acceptability and they constantly receive viewers' comments. Second, there is a point to be considered whether political broadcasts should be allowed to contain material which may be shocking in order to put across a serious political message. It is not an issue likely to have been given particular consideration when the Broadcasting Act 1990 was passed, and, since under that Act the same rule applies to political broadcasting as to other broadcasts, it was not an issue which the broadcasters could evaluate. Third, on the question whether Pro Life's broadcast should have been immune from the taste and decency requirement applicable to other broadcasts, arguments can be put on either side, both of a narrower and of a broader kind. On the narrower front, there was the importance to Pro Life of being able to put across its message in a dramatic way, but there was also the likelihood of distress which would be caused to many people viewing the programme in their own homes, including women who had undergone abortions for one reason or another.

On a broader level, the arguments would include general arguments about the importance of freedom of political speech but also the concerns expressed by the Electoral Commission in its 2003 report on party political broadcasting (to which Lord Hoffman referred) about the possibility that any lobby group might become able to transmit into people's homes material of an offensive nature by registering itself as a political party. Fourth, there happens to be a Communication Bill before Parliament. There is therefore now an opportunity for a democratic debate about these matters. Fifth, the decision of the House of Lords has the benefit of allowing the question whether taste and decency standards ordinarily applicable to broadcasts should be applied in the same way to political broadcasts to be determined as a result of that process of debate rather than pre-empted by judicial decision.

I have referred to the obviousness or doubtfulness of an apparent or alleged infringement of human rights as a factor of general relevance when a court is considering a human rights challenge, whether to the compatibility of legislation with the Convention or to an executive decision. If it may reasonably be concluded that the legislation is compatible with the Convention, or can be read in a way which is compatible with it, or that the decision under review was not unlawful, the court should so conclude. To interpret legislation in a way which does not correspond with its primary meaning, or to declare it incompatible with the Convention, or to hold that the executive has acted unlawfully, may be necessary and right, but it should never be done lightly.

Similar to this principle, if not an alternative way of putting it, is the concept of "latitude". In $R$ (Pro Life) v BBC Lord Walker quoted a passage from Michael Fordham's Judicial Review Handbook (third edition, 2001), which included the following:

"Hand in hand with proportionality principles is a concept of 'latitude' which recognises that the court does not become the primary decision-maker on matters of policy, judgement and discretion, so that public authorities should be left with room to make legitimate choices. The width of the latitude (and the 
intensity of review which it dictates) can change, depending on the context and circumstances."

I have referred also to the question of the expertise of the court, compared with the expertise of the author of the policy under review. If the court does not have the necessary knowledge or expertise to be able properly to determine whether there has been a breach of the claimant's human rights, it has no option but to reject the claim. This can present acute difficulty where there is a prima facie interference with the claimant's rights but the court is unable to look into or behind the public authority's evaluation of the circumstances relied on to justify it. The classic instance is a case involving national security.

A v Home Secretary [2003] 2 WLR 564 provides a recent example. The Court of Appeal upheld the lawfulness of section 23 of the Anti-Terrorism, Crime and Security Act 2001, providing for the detention of non-nationals if the Home Secretary believes that their presence in the UK is a risk to national security and suspects that they are terrorists, but for the time being they cannot be deported because of fears for their safety or other practical considerations. The Home Secretary had based his decision about what was necessary in the interests of national security on information and advice from the Security Service. Brooke LJ said:

"Unless one is willing to adopt a purist approach, saying that it is better that this country should be destroyed, together with the ideals it stands for, than that a single suspected terrorist should be detained without due process, it seems to me inevitable that the judiciary must be willing ... to put an appropriate degree of trust in the willingness and capacity of ministers and Parliament, who are publicly accountable for their decisions, to satisfy themselves about the integrity and professionalism of the Security Service."

The language of the first half of that sentence is reminiscent of the title of a book by Chief Justice Rehnquist of the United States, "All The Laws But One" (1998), about civil liberties in war time. The title came from a message from President Lincoln to a special session of Congress on 4 July 1861, justifying his decision to suspend habeas corpus in order to enable the military to deal summarily with rioting mobs in Baltimore, who threatened to prevent the reinforcement of the capital by troops from the north passing through Baltimore by rail road. In his message the President asked rhetorically:

"Are all the laws, but one, to go unexecuted, and the government itself to go to pieces, less that one be violated?"

Having traced the history of civil liberties from the American Civil War through two World Wars, including the internment in the Second World War of more than one hundred thousand people of Japanese origin, and the resulting court cases, the author notes in his final chapter that the courts have tended to give decisions in favour of civil liberty more often when the case has been ultimately decided after the end of hostilities than during them. Although we like to say that during wars the laws are not silent, the sober reality appears to be that in times of national emergency judges are as much affected by majoritarian sentiment as the society of which they are a part. In this country it is difficult to explain otherwise the judgments of four of the five Law Lords in Liversidge $v$ Anderson [1942] AC 206.

Another person interned in the same month as Robert Liversidge was a distinguished former judge and chairman of the Law Commission, Sir Michael Kerr. He gave an account of his experiences in his autobiography "As Far As I Remember". He was detained in May 1940 as he was coming to the end of his first year as an undergraduate reading law at Cambridge University. Also detained was one of his supervisors, Kurt Lipstein, who is happily still supervising undergraduates at the age of 94 and recently told me something about his memories of internment. From both accounts there is a picture of bureaucratic muddle and incompetence. Michael Kerr was eventually released after six months, as a result of some enterprising lobbying by his mother and an intervention by his former headmaster. He then joined the RAF and became a pilot.

For a person to be deprived of his liberty at a time of national emergency because of security intelligence which cannot be verified in a court of law on ordinary rules of evidence may be a price which has to be paid in the interests of the safety of the realm, but there is no reason why a person should be detained through bureaucratic bungling or laziness. It would therefore be going much too far to say that the courts cannot scrutinise interference with human liberty where the grounds advanced are the need to protect the safety of the state at a time of emergency. The area which a court is qualified to inquire into may be restricted, but in matters of human freedom half a loaf is still better than no bread. In this regard there is a significant difference between the position of those detained in 1940 and asylum seekers who are currently being detained on suspicion of being terrorists. In 1940 detainees had no form of judicial redress. The cases of detained asylum seekers are subject to a form of judicial investigation.

The courts also have an important role to play in policing not only the circumstances in which national security may justify interference with a person's human rights, but also the extent of the interference which may be justifiable.

Terrorism, like war, can present difficult challenges to our legal system. Professor Alan Dershowitz of Harvard Law School, in a book entitled Why Terrorism Works (2002, Yale University Press), gives a hypothetical example of a captured terrorist suspect who knows that a time bomb has been set which is intended to kill a large number of innocent civilians. The question which he asks is whether it would be legitimate in the last resort to use torture to extract information from the suspected terrorist in order to prevent massive loss of life. He has no doubt about the views of the public. He says: 
"It is clear that if the preventable act of terrorism was of the magnitude of the attacks of September 11, there would be a great outcry in any democracy that had deliberately refused to take available preventive action, even if it required the use of torture. During numerous public appearances since September 11 2001, I have asked audiences for a show of hands as to how many would support the use of non-lethal torture in a ticking bomb case. Virtually every hand is raised. The few that remain down go up when I ask how many believe that torture would actually be used in such a case."

In his stimulating and provocative discussion of the issue, Professor Dershowitz notes that the debate over the use of torture goes back many years, with Bentham supporting it in a limited category of cases on utilitarian grounds and Kant opposing it as part of his categorical imperative against improperly using people as a means for achieving noble ends. The Supreme Court of Israel has outlawed the use of any physical pressure on suspects.

Article 3 of the ECHR is unqualified:

"No one shall be subjected to torture or to inhuman or degrading treatment or punishment."

There can be no doubt that it would be the duty of an English court to investigate any allegation of a breach of this Article, and that national security could afford no ground for the court restricting its investigation. I am glad that this is so, because to take the Benthamite approach would be to start on a downward slope too slippery for there to be any safe or acceptable limit. It is interesting to note from Professor Dershwitz's book that Bentham's approach on this subject has itself been criticised by two Bentham scholars, W L Twining and P E Twining, on utilitarian grounds. They argue:

"The circumstances are so extreme in which most of us would be prepared to justify resort to torture, if at all, the conditions we would impose would be so stringent, the practical problems of devising and enforcing adequate safeguards so difficult and the risks of abuse so great that it would be unwise and dangerous to entrust any government, however enlightened, with such a power. Even an out-and-out utilitarian can support an absolute prohibition against institutionalised torture on the ground that no government in the world can be trusted not to abuse the power and to satisfy in practice the conditions he would impose." (Twining and Twining, Bentham on Torture, pp 348-49).

Professor Dershowitz considers whether satisfactory limits could be imposed by the court issuing a torture warrant, but I do not see on what basis a court could determine what would be a morally or legally acceptable limit of ill-treatment. Professor Dershowitz also recognises that the legitimisation of torture by a leading democracy would provide a welcome justification for its use in other parts of the world.

Having talked about general factors and discussed some of the more particular issues which may arise in relation to them, where does the discussion lead with regard to the concerns expressed by Professor Campbell and others about the democratic legitimacy of the role of the courts under the Human Rights Act?

Under the Act, as in any area of the law, the judge needs to be conscious at all times that while he may be involved in fashioning the law he is also bound by the law; and that, in so far as he is involved in developing the law, the task is to do so in accordance with precedent, reason and principle. In his celebrated series of lectures published as The Nature of the Judicial Process (Yale University Press, 1921) Benjamin Cardozo said:
"The judge, even when he is free, is still not wholly free. He is not to innovate at pleasure. He is not a knight-errant roaming at will in pursuit of his own ideal of beauty or of goodness. He is to draw his inspiration from consecrated principles. He is not to yield to spasmodic sentiment, to vague and unregulated benevolence. He is to exercise a discretion informed by tradition, methodised by analogy, disciplined by the system, and subordinated to 'the primordial necessity of order in the social life'. Wide enough in all conscience is the field of discretion that remains."

In the constitutional field the judge must have a proper sense of the roles of the legislature and the executive necessary for the ordering of social life, but must also have a deeper sense of lasting national values, as distinct from passing fashions or his own particular predilections. As to the latter, there will be no respect for as judge's decision in a controversial case if it appears to rest simply on a personal preference.

I believe that possibly the most important, but least appreciated, impact of the Human Rights Act is at the Parliamentary stage, because the requirement under section 19 that a minister in charge of a Bill must either certify that in his view its provisions are compatible with the Convention or state that he is unable to do so requires the Bill to have gone through rigorous scrutiny before it is passed.

In the courts, many points under the Human Rights Act have been raised but comparatively few have attracted public attention. Professor Campbell's observation that the powers are subject only to political factors, such as hostile public reaction to court decisions, omits the constraining factor of the courts' own search for principle, which has been a notable feature of the leading cases under the Act.

As to the future of judicial review and its role in a representative democracy with a common law tradition, I would quote the following words written by Archibald Cox, sometime Professor of Law at Harvard University, US Solicitor General and Watergate Special Prosecutor until sacked by President Nixon, in a book entitled The Court and the Constitution (Houghton Mifflin Company, 1987):

"The future of judicial review probably depends in good
measure on whether the view that law is only policy made by
courts carries the day in the legal profession, or whether room 
is left for the older belief that judges are truly bound by law both as a confining force and as an ideal search for reasoned justice detached so far as humanly possible from the interest and predilections of the individual judge. The heavily policyorientated view not only carries the dangers of the 'despotism of an oligarchy' of which Thomas Jefferson spoke, but it cuts off the taproots of judicial independence and legitimacy. The older view, I believe, also conforms more closely to the people's expectations. Surely, if the people could be asked whether judges should decide without restraint, a heavy majority would reply, 'no, they should follow the law'. But if asked whether precedent should always be binding, surely the majority would reply, 'no, precedent should not always be binding. Sometimes past law was unjust'.

In its creative aspects, wise constitutional adjudication seems to me to draw additional legitimacy from, and is limited by, a delicate symbiotic relationship. The great opinions of the past shaped the Nation's understanding of itself. They told the people what they were by reminding them of what they might be. But while the opinions of the Court can sometimes be the voice of the spirit reminding us of our better selves, the roots of such decisions must be already in the people. The aspirations voiced by the Court must be those that the community is willing not only to avow but in the end to live by. The legitimacy of the great creative decisions of the past flowed in large measure from the accuracy of the Court's perception of this kind of common will and from the Court's ability, by expressing the perception, to strike a responsive chord equivalent to the consent of the governed. To go further - to impose the Court's own wiser choice - is illegitimate."

It is that sense of the judicial role, with its emphasis on the search for reasoned justice, respect for precedent and sensitivity to society's traditions and values, which I believe can and should inform and constrain the way in which judicial review is developed. No doubt judicial mistakes will be made. All democracy is an experiment. But establishing a legal framework for the protection of fundamental human rights within the wider framework of our form of self-government through representatives is surely a worthwhile part of the experiment.

An area in which public opinion polls have for decades shown a large majority of the British public believing the judges to be out of touch with society and doing a bad job is criminal law and especially sentencing. This poor general opinion has been remarkably consistent and has existed independently of crime trends and even dramatic changes in criminal justice policies (Hough and Roberts (1999), "Sentencing Trends in Britain: Public Knowledge and Public Opinion" (Punishment and Society, Vol. 1). In 1996 the British Crime Survey, as well as asking usual questions about attitudes to sentencing, also asked much more searching questions in order to assess the accuracy of public knowledge and beliefs about crime and sentencing and to test people's preferred sentences on the facts of a particular case. (Hough and Roberts, "Attitudes to
Punishment: Findings from the British Crime Survey" (Home Office Research Study No. 179).) The survey covered a nationally representative sample of 16,348 households in England and Wales, and the response rate was $82.5 \%$. The results were illuminating.

In answer to general questions, $82 \%$ thought that judges were out of touch with the public; 79\% thought that sentences were too lenient; and only 20\% thought that judges were doing a good job. Unsurprisingly, there was a strong correlation between those who thought that judges were out of touch, those who thought that they were over lenient, and those who thought that they were doing a poor job. Ninety percent of those who thought that judges were out of touch also felt that sentences were too lenient and $92 \%$ of those who thought that judges were doing a poor job felt that sentences were too lenient.

Questions about the trends in recorded crime, the proportion of recorded crime involving violence and the courts' use of imprisonment for different types of crime (rape, mugging and burglary) revealed very considerable misperceptions. Asked whether they would say that there was more reported crime, less crime or about the same amount compared with two years earlier, $4 \%$ gave the correct answer, which was that recorded crime had gone down. Nearly half thought that it had gone up a lot. Asked whether they thought that the percentage of recorded crime which involved violence or the threat of violence was under $10 \%$, between $10-29 \%$, or upwards of $30 \%$, only $3 \%$ gave the correct answer, which was that it was under $10 \%$. Seventy-eight percent thought that it was over 30\%.

There were very substantial under estimates of the courts' use of imprisonment for rape, mugging and burglary. The respondents' median estimate of the proportion of rapists sent to prison was $50 \%$, whereas the true figure was over 95\% (and that excludes those who were sent to secure mental hospitals). The median estimate of the proportion of adult muggers sent to prison was 35\%, whereas over $90 \%$ of adult male offenders convicted of any form of robbery in 1995 were sent to prison. (This figure would have included other forms of robbery apart from mugging, so the proportion sent to prison for offences of mugging may have been lower, but it would still have been far higher than the great majority of respondents believed.) The respondents' median estimate of the proportion of male adult house burglars sent to prison was 30\%, whereas in 1995 61\% of convicted adult male house burglars were imprisoned.

Respondents were also asked what percentage of such offenders ought to go to prison. The mean responses were 94\% for rapists and $84 \%$ for muggers, figures in line with the courts' actual practice, in contrast with the respondents' general answers that the courts were overlenient. For burglars, respondents were asked a general question and given a specific example. On the question what proportion of adult house burglars should be sent to 
prison, the mean figure was $80 \%$, with $42 \%$ saying that all adult burglars should go to prison.

The specific example was based on a true case of a man aged 23, with previous convictions for burglary, who pleaded guilty to a day time burglary of a cottage belonging to an elderly man while he was out. The defendant took a video worth $£ 150$ and a television which he left damaged near the scene of the crime. He was given a three year sentence in the Crown Court, which was reduced on appeal to two years.

The respondents were divided into two groups. One group was provided with a list of sentencing alternatives and asked to choose one or more punishments. The other group was not provided with a list of alternatives. The object of splitting them in this way was to test the hypothesis that the top of the head reaction of most people is to think first about imprisonment, and that their opinion my change when they consider other alternatives.

Of the group provided with a choice of alternatives, 54\% favoured immediate imprisonment. Of the group not provided with a menu of options, $67 \%$ favoured immediate imprisonment. Of those who chose immediate imprisonment, the median term favoured was 12 months.

This study does not stand alone. Similar lessons can be learned from the 1998 and 2000 British Crime Surveys (see Mattinson and Mirrlees-Black (2000) "Attitudes to Crime and Criminal Justice: Findings from the 1998 British Crime Survey" (Home Office Research Study No. 200); Mirrlees-Black (2001) "Confidence in the Criminal Justice System: Findings from the 2000 British Crime Survey" (Home Office Research Findings No. 137)). There were differences in matters of detail. For example, in 1998 the categories of police recorded violence were divided into more and less serious violence, the latter including common assault. Including common assaults, the proportion of violent crime rose to $12 \%$; without it, the proportion was $8 \%$; but the pattern of great overestimation of the proportion of violent crime was similar.

Researchers have recently carried out a detailed survey for the Home Office of perceptions among jurors. The results have not yet been published, but it will be interesting to see to what extent the results of opinion polls about judges being out of touch and bad at their job are supported or contradicted by the experiences of those who have served as jurors.

It is not surprising that the public should have mistaken beliefs about levels of crime, particularly violent crime, and patterns of sentencing. Serious violent crimes are newsworthy. The media also naturally report cases where they think that the sentencing is questionable.

Nor is it particularly surprising that general responses to opinion poll questions about how a particular kind of offender should be dealt with may differ markedly from responses when more information is given. When people are asked a general question about a type of crime, it is natural for them to think immediately about the worst kind of examples. The more that people are told about a case, the more difference it is likely to make to their view of the appropriate penalty. Many examples could be given to show this.

An early study conducted in Canada compared the responses to sentencing of two groups of people. One group read a newspaper account of a sentencing decision involving a case of assault. The second group was given a summary of the court documents. Both groups were asked what they thought of the sentence that had been imposed. $63 \%$ of the group which read the newspaper report thought that the sentence imposed was too lenient. The majority of the group that read the summary of the court documents thought that the sentence was too severe (see Doob and Roberts (1983): "An Analysis of the Public View of Sentencing" (Canadian Department of Justice), cited in Penal Populism and Public Opinion by Roberts, Stalans, Indermaur and Haugh (2003 Oxford University Press, 29-30)).

In Canada a survey conducted in 1988 found that four out of five respondents thought that convicted murderers should never be paroled (Roberts (1988) Early Release: What do the Canadian Public Really Think? (Canadian Journal of Criminology 30: 231-39)). By contrast, under section 745.6 of the Canadian Criminal Code almost all inmates convicted of murder and sentenced to life imprisonment may apply for a jury review of their parole eligibility date. Prisoners serving life sentences for first degree murder must serve 25 years before becoming eligible for parole, but at the 15 year point they can ask a jury to review their parole eligibility date. In four out of five applications to date, juries have reduced the number of years that the prisoner must serve prior to becoming eligible for parole (Roberts (2002) "Determining Parole Eligibility Dates for Life Prisoners: Lessons from Jury Hearings In Canada" (Punishment and Society, Vol. 4: 103-14)).

It is easy, but I think unfair, to blame the media for public misapprehensions about crime and sentencing. It is simply a fact of life that stories of serious crime make news, especially if the sentence is thought by the victim or by the reporter to be too lenient.

What is undesirable is that uninformed, or misinformed, generalised opinions about over-leniency of the courts should feed into the fixing of sentences and sentencing policies in the name of democracy in order to meet supposed public demand.

Unfortunately this has happened, and the phenomenon is not peculiar to Britain. A recent book by four criminologists, Roberts, Stalans, Indermaur and Hough, entitled 'Penal Populism and Public Opinion' (2003 Oxford University Press) shows that there has been a similar pattern over the last decade in Australia, Canada, England and Wales, New Zealand and the United States. In all of these countries there has been a marked rise in sentencing 
in recent years, corresponding with widespread public beliefs that crime has been rising sharply, although reported crime rates have mostly been falling or static. The rise in sentencing has not been research based or rationally explained. It has mainly been a response to what the authors describe as penal populism, a term which they use to describe demands for stronger penalties based on general public attitudes that courts are soft on criminals rather than a more careful study of informed public opinion. They argue that:
"A central feature of populist strategy is to accept public opinion as an unproblematic entity that has a distinct shape and direction. This view is contradicted by the findings of numerous studies on public opinion in relation to crime and punishment which find that it is malleable, is based on a series of false assumptions, and will readily respond to reasonable propositions or alternatives" (p. 88).

The authors agree that public attitudes must and should be taken into account in sentencing policy, but they say:

\begin{abstract}
"Improving the measurement of public attitudes requires closer adherence to best practices in designing polls. For example, it is bad practice to ask people questions when it is clear that the majority lack the information necessary to make a sensible response. It is bad practice to use loaded terms: for example, asking if the courts are 'tough enough on persistent criminals' is guaranteed to elicit agreement from the vast majority of the population. Although these are obvious enough lessons, ... many surveys of the public continue to ignore them. ... Better measurement of public attitudes also involves placing the results of an opinion poll in some context. This context would include information about what people would know of the problem being explored in the poll, as well as the results of previous polls dealing with the same issue."
\end{abstract}

In this country some part of the rise in sentencing has been due to mandatory sentences, but much more has been due to a general rise in sentences imposed by courts within their discretion. We do not have sentencing by jury, which would be a form of mini-plebiscite, not only because that would be likely to produce wide inconsistencies, but also because part of a judge's training is to learn the approved brackets of penalty for different kinds of offence, to gain knowledge and understanding of the different types of penalty and their general success rates, and to evaluate various factors in the case before the court. Setting the appropriate brackets is not a matter of science, and one of the important factors is public opinion. If judges are to take into account public opinion in a rational way, as is plainly desirable, it seems to me that they need more assistance in understanding what properly researched public opinion shows. A sentencing advisory council may be the best body for evaluating the available material and giving guidance to judges, which would be publicly available. In the USA membership and activities of such commissions have tended to be influenced by political considerations. While Parliament has a right to set maximum and minimum penalties, it seems to me a much better that a panel responsible for recommending appropriate brackets of sentence within those limits should do so on a non-partisan basis, taking full account of properly researched views of the public. Such a body should also help to dispel some of the misconceptions which have affected present levels of confidence in the criminal justice system.

We already have a Sentencing Advisory Panel, and its views are taken into account by the Court of Appeal in setting sentencing guidelines. Under the Criminal Justice Bill it is proposed that the Sentencing Advisory Panel should be retained but there should also be a Sentencing Guidelines Council, containing a majority of judicial members and some lay members. It is also proposed that a sentencer who departs from guidelines issued by the council will be required to state the reasons for doing so.

Whatever its membership, the quality of the guidance issued by such a body would be only as good as the material on which it is based. By way of illustration, the findings of a recent publication by the Patterns of Crime Group within the Home Office, entitled Crime in England and Wales 2001/02, show that perceptions of crime differ markedly between tabloid and broadsheet readers, but it would not be satisfactory if the council's recommendations were to vary according to whether it consisted predominantly of broadsheet or tabloid readers.

If the council's recommendations are to be based on something more objective than the individual perceptions of its members and their unscientific impressions of what the public would want, it needs to be in a position to obtain or commission properly researched and reliable information, and to inform the public (including sentencers) how it has arrived at its conclusions. This is particularly important since its guidelines will carry legal force.

Twenty-five years ago Professor Nigel Walker wrote in the first chapter of his book 'Sentencing in a Rational Society' that:

"If the criminal law as a whole is the Cinderella of jurisprudence, then the law of sentencing is Cinderella's illegitimate baby."

The key principles underlying any fair and wise system of sentencing are, first, that sentencing policies should be worked out on an informed and rational basis, taking into account the objects of punishment (generally accepted to be retribution, prevention, deterrence and reform), crime trends, informed public opinion, the experience of other countries and the success rates attaching to different types of sentence; and second, that individual sentences should be determined, in Mill's words, with calmness and impartiality. If that is not only done (as I believe happens to a greater extent than is generally appreciated, although we can do better) but importantly seen to be done, the system ought to deserve the confidence and acceptance of the public.

Sir Roger Toulson 